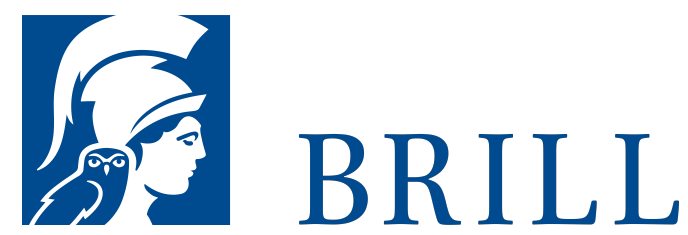

\title{
Towards a Right-Libertarian Welfare State
}

\section{An Analysis of Right-Libertarian Principles and Their} Implications

\section{Author:Joachim Wündisch}

The book derives the welfare state from right-libertarian principles and, therefore, arrives at policy prescriptions of the political left based on the philosophical principles of the political right. For that purpose the book offers a detailed analysis of right-libertarianism with a particular focus on the work of Robert Nozick. Further, it engages economic and sociological theory and addresses questions of transgenerational compensation, causation, historical wrongs, and collective responsibility. The discussion of transgenerational compensation includes an in-depth treatment of the non-identity problem. The final chapters spell out the arguments' specific implications for public policy and philosophical theory.

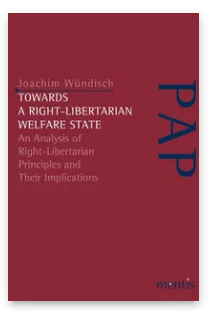

Pages: 181 Seiten Language:

English

Subjects:

General,

Philosophy

Publisher: Brill | mentis

Series:

Perspektiven der Analytischen Philosophie

E-Book (PDF) Released online: 25 Apr 2014

ISBN: 978-3-

89785-987-6

List price

Paperback

Publication date: 25 Apr 2014

ISBN: $978-3^{-}$ 89785-844-2 List price 
For more information see brill.com

Order information: Order online at brill.com +44330 333 0049 | customerservices@brill.com Submission information: brill.com/authors

Titles published by Brill | Fink, Brill | mentis or Brill | Schöningh: +49(o)715413279216| brill@brocom.de 